\title{
THE PROBLEM OF IRREVERSIBLE SHOCK
}

\author{
By F. G. SmIDdy, F.R.C.S. \\ Department of Surgery, Leeds
}

The term ' shock' was first used by the French surgeon, Le Dran, in 1743 when describing the effects of gunshot wounds; however, he used this term to describe the act of collision of a missile with the body rather than the resulting functional damage. Between the 18th and 2oth centuries the meaning of this term has gradually altered until now it is used to describe a syndrome, one of the main features of which is severe hypotension, but even so there is no definition of shock yet available which meets with universal approval among the many investigators active in this field. However, for the clinician the problem is somewhat simpler and shock is generally considered to be present when a patient becomes hypotensive, with an associated rise in the pulse rate and shallow respiration. In severe cases peripheral cyanosis develops and in these circumstances the clinician will frequently apply the term 'peripheral circulatory failure' emphasizing his instinctive belief that the cause of this syndrome lies in the smaller blood vessels rather than centrally, i.e. in the myocardium. Whilst many varied therapeutic methods have been used to reverse this state, none is universally successful and it is with the problem of why reversible hypotension becomes irreversible that this paper seeks to deal.

Two concepts have been advanced in recent years, each strongly advocated by their supporters. These concepts, whilst in many ways divergent, have some points of similarity.

The main advocates of the first concept which will be described are the investigators at New York University initially led by the late Dr. Ephriam Shorr and latterly by B. Zweifach. The latter's interest in the problem of irreversible shock has grown from a study of the microcirculatory derangements which occur in visceral areas during ' shock' produced by graded haemorrhage. The meso-appendix of the rat and the omental circulation of the dog have been studied in great detail and Zweifach et al. (1944) have shown that in these tissues the small blood vessels respond in two distinct ways to both trauma and progressive haemorrhage. In the first stage, when the experimental animal will recover following restoration of the blood volume, the small vessels appear to be over-active, as is shown by the increase in spontaneous vasomotion and the selective contraction of precapilliary sphincters so that the flow of blood becomes restricted to central channels. Whilst such a circulation is abnormal it is sufficiently effective to maintain aerobic metabolism within the tissues affected. In the second or irreversible phase, when the animal responds only temporarily, if at all, to blood replacement therapy, progressive sequestration and trapping of blood occurs in the capillary bed so that the effective blood volume diminishes; at this stage the oxygen tension in the tissues falls with the result that the aerobic pattern of the metabolism is disturbed; transfusion at this stage merely serves to fill atonic vascular channels; the blood pressure cannot be maintained and death of the animal is inevitable.

In 1948 Shorr et al. found evidence which led them to conclude that these vascular changes were the result of circulating vaso-active materials. They postulated that in the first phase these substances were predominantly vaso-constrictor, and in the second or later irreversible stage vasodepressor, so that even in the presence of adequate quantities of noradrenaline paresis of smaller vessels occurred. This latter suggestion is in keeping with the common clinical observation that many cases of profound hypotension, especially those due to intra-abdominal sepsis, fail to respond to parenterally administered hypertensive drugs. Chambers and Zweifach (1947) considered that the hypoxic kidney was the source of the vaso-excitory material, but even to date its precise identity has not been established. Shorr et al. (195I), however, were able to identify the vasoinhibitory agent as an iron-containing protein, ferritin. In the hypoxic phase of shock they have suggested that this compound is liberated from the liver in a sulphydryl form. At first it was believed that this compound exerted its effect by a direct paralysing action on the smaller blood 
vessels, but more recently Green et al. (1956) have postulated that sulphydryl ferritin catalyses the oxidation of naturally occurring vaso-constrictor materials, thus preventing their action. Zweifach points out, however, that the discovery of vasotoxic agents in shock does not necessarily mean that these agents are primarily responsible for the development of irreversibility since vascular decompensation in differing regions need not necessarily develop as a consequence of a single humoral mechanism. A further difficulty in the acceptance of this hypothesis is that Frank et al. (1952) were unable to produce vascular paralysis or hypotension by sulphydryl ferritin in animals subjected to prior hepatectomy and nephrectomy. Such animals unable to metabolize or excrete the injected ferritin should have been very susceptible to its action.

The second recent hypothesis put forward to explain the irreversible collapse of the circulation in shock is the bacterial factor of Fine and his collaborators (1952). Briefly, Fine considers that the irreversible circulatory changes which follow prolonged hypotension result from the noxious action of bacterial products upon the smaller blood vessels; the nature of these products being bacterial endotoxins and their source the bowel. The main support for this hypothesis comes from the work of Jacob et al. (1954) in the dog using the elevated reservoir technique for the production of haemorrhagic hypotension. Using this method the dog normally dies after retransfusion if the volume of the blood self-transfused from the reservoir during the course of a hypotensive experiment exceeds 40 per cent. Jacob et al. (1954) found, however, that the normal lethal response to this experiment could be aborted if antibiotics such as neomycin, terramycin or penicillin were administered orally at some time prior to the production of haemorrhagic hypotension. In such pretreated animals the volume of ' take up' from the elevated reservoir was found to be negligible even after prolonged periods of hypotension, and secondly, following retransfusion a good pressor response occurred, which was maintained, so that the majority of animals survived indefinitely.

This general hypothesis is indirectly supported by the great similarity which exists between the terminal stages of endotoxaemia and haemorrhagic shock (Weil, McClean and Vischer, 1956), and by investigations which have shown that animals such as the dog are extremely sensitive to bacterial invasion after even transient periods of hypotension (Schweinburg et al., 1954). It has also been shown by Schweinburg that smaller animals such as the rabbit become increasingly sensitive to the vascular effects of bacterial endo- toxins when shocked even for short periods, the minimum lethal dose of such toxins falling to $1,100,000$ th of the original during the course of one and a half hours of hypotension. In 1955 Frank and Pillemer showed by measurement of the plasma properdin titre during hypotension that the non-specific antibacterial defence mechanisms were also injured, and in 1956 Rutenburg et al. demonstrated the presence of a circulatory leucotoxin which developed to an increasing degree as the period of hypotension lengthened.

More recently Schweinburg et al. (1958) have shown that a transferable toxin is present in the plasma of animals dying after prolonged haemorrhagic hypotension; this toxic material present in Seitz-filtered fractions of plasma, although incapable of killing the normal healthy animal, was found to be extremely lethal to those subjected to short periods of hypotension. The possibility that this toxin was derived from Clostridia, normal inhabitants of the tissues of the dog, was ruled out by prior treatment of the recipient animals with Clostridial antitoxins. These various investigations represent some of the main lines of evidence upon which Fine et al. support their hypothesis.

In $195^{8} \mathrm{Zweifach}$ et al. reported an investigation tending to disprove the main thesis of Fine and his collaborators which has been previously outlined, although leaving untouched the subsidiary investigations. Working in the Lobund Institute with completely sterile rats, Zweifach (1958) has shown that these animals react to haemorrhagic shock in precisely the same manner as the normal animal, that is to say, they exhibit no specific resistance to the effects of graded haemorrhage. If Fine's hypothesis is correct it might reasonably have been expected that such animals would have an increased resistance to shock. In view of these results Zweifach not unnaturally argues that bacteria or their products cannot be a primary aetiological factor in the pathogenesis of shock. It is, however, possible that the failure of resistance in these animals is explicable in terms of their altered lymphoid tissues, such changes reducing their capacity to deal with even traces of bacterial contamination.

Whilst this brief discussion suggests that the two major concepts have little in common, it is interesting to observe that in both the liver is regarded as an organ of great importance in the pathogenesis of 'irreversibility.' Emphasis on the precise reason for the importance of this organ, however, differs according to the view accepted. Zweifach, Shorr et al. consider that this organ is important as the source of sulphydryl ferritin, whereas to Fine and his protagonists its importance in shock lies not in the liver cell 
per se but in the reticulo-endothelial component. As long ago as 1946 Frank et al. observed that perfusion of the portal vein of the dog by crosscirculation with arterial blood from a normal donor animal prevented the development of irreversibility even after prolonged periods of hypotension. The explanations offered for this phenomenon have changed as further investigators have shed new light on the subject and it is now considered that the favourable effects of such perfusion experiments result from the protection of the reticulo-endothelial system from damage during the hypotensive period, with the result that the ability of this system to clear endotoxins from the circulation is maintained throughout the shock period, so saving the vascular system from destruction. The importance of the reticuloendothelial system in haemorrhagic shock is shown firstly by the observation of Schweinburg et al. (I955) previously discussed, showing the increased sensitivity to bacterial endotoxins in the shock period, and furthermore by the observation of $Z$ weifach and Benacerraff (1958) who showed that the clearance rate of carbon or radioactive chromium phosphate was greatly reduced during graded haemorrhage.

These observations suggest that the production of a hyperactive reticulo-endothelial system should favourably influence the outcome of experimental shock. Such hyperactivity can be induced by repetitive daily sublethal injections of endotoxin which finally produces a condition of tolerance in which the minimum lethal dose is increased manyfold. The development of tolerance during this procedure can be readily demonstrated by the modifications which occur in the fever response, since the second rise in temperature which normally follows an injection of endotoxin is abolished (Farr et al., 1949). When tolerance has been established an animal such as the rabbit will then survive lethal degrees of haemorrhagic shock (Smiddy and Fine, 1957). Similarly, Zweifach (1957) has shown that tolerance to endotoxins results in protection of the rat against both haemorrhagic and drum shock.

Whilst at first such observations would appear to be additional evidence in support of the bacterial hypothesis, on reflection they contribute little to this aspect of the problem since the reticulo-endothelial system can be stimulated and enhanced to the point of pyrogenic tolerance by a variety of materials such as Zymosan and denatured albumin. Such animals will then survive lethal degrees of haemorrhagic shock. Thus, the response of the reticulo-endothelial system to repeated stimulation by endotoxin is non-specific in character with the result that cross-tolerance to many lethal forms of stress occurs.
Further evidence demonstrating the importance of the reticulo-endothelial system is available; the tolerant animal when given a blockading dose of Thorotrast prior to shock behaves in precisely similar fashion to the normal unprotected animal (Smiddy, I957), and in the normal animal such blockage results in a diminished capacity of the animal to withstand hypotension (Fine, I958).

Both schools of thought, therefore, agree that the liver is of great importance in determining the outcome of shock by whatever method this syndrome is induced, and in addition both are now agreed that the reticulo-endothelial component of this organ is an important element in defence. Assuming that bacteria or their products are an important factor in ' shock,' the importance of the liver is readily explicable, but as yet $Z$ weifach and his collaborators have been unable to interpret the ferritin hypothesis on the basis of this system.

A further complicating factor has recently arisen from the observations of Landy and Shear (1957) who have found that body tissues contain high molecular weight polysaccharide components possessing many of the properties of the bacterial endotoxins. The possibility arises that during the hypotensive phase such materials could be liberated into the general circulation, disrupting smaller blood vessels. Indeed, it has been shown that a variety of phenomena can be induced by plasma obtained from rabbits subjected to prolonged hypotension. Such plasma possesses leucopenic, pyrogenic and Schwartzman-provoking activities (Smiddy, 1957; Rutenburg, I958), suggesting the presence of endotoxins or endotoxinlike materials in the circulation without indicating their origin. However, Ravin et al. (1958) have shown that these properties, in particular the Schwartzman-provoking capacity, are abolished when animals are treated with antibiotics prior to the hypotensive procedure, evidence which leads us back once more to the importance of the bacterial factor in this syndrome.

From the foregoing discussion it must be obvious to the reader that in spite of the intensive investigation of the problems associated with the development of irreversibility in experimental shock we are little further advanced towards a solution. However, in the search several interesting observations have been made which may at some time have an application in clinical medicine.

To conclude, one might quote from Sir Astley Cooper's 'Dictionary of Practical Surgery,' 'Surgeons are in the habit of saying men died of shock without asking themselves very strictly what is meant by the term,' one might add, 'or by the mechanisms involved.'

Bibliography continued on page 557 
present in general surgical units. The desirability of prompt exploratory thoracotomy is stressed.

\section{Acknowledgments}

I should like to thank Professor A. M. Boyd and Mr. G. O. Jelly for permission to report these cases and for their helpful advice.

\section{BIBLIOGRAPHY}

BIGGER, G. A. (1940), Med. Ann. Distr. Columbia, 9, 390. BISHOP, L. H., Jr., ESTES, E. H., Jr., and McINTOSH, H. D. (1956), f. Amer. med. Ass., 162, 264.

BLALOCK, A., and RAVITCH, M. M. (1943), Surgery, 14 , 157. BLOCK (1882), 'Verhandlungen der deutschen Gesellschaft für Chirurgie, elften Congress, Berlin,' Part I, p. 108

CAPPELEN, A. (1896), Norsk Mag. Laegevid., 11, 285.

EHRENHAFT, J. L., and TABER, R. E. (1952), f. thorac. Surg., 24, 355 .

ELKIN, D. C., and CAMPBELL, R. E. (1951), Ann. Surg., 133, 623.
FISCHER, G. (1868), Arch. klin. Chir., 9, 571.

GRISWOLD, R. A., and DRYE, J. C. (1954), Ann. Surg., 139, 783.

HARKEN, D. E. (1946), Surg. Gynec. Obstet., 83, 117.

JAHNKE, E. J., Jr., and SEẸLEY, S. F. (1953), Ann. Surg., 138 158.

JORDAN, P., Jr., and WILSON, G. E., Jr. (1953), Surg. Clin. N. Amer., 33, II 5 .

LYONS, C., and PERKINS, R. (1957), American Surgeon, 23, 6, 507.

MAGUIRE, C. H., and GRISWOLD, R. A. (1947), Amer. F. Surg., 74, 721.

MAYNARD, A. DE L., CORDICE, J. W. V., Jr., and NACLERIO, E. A. (1952), Surg. Gynec. Obstet., 94, 605 .

NACLERIO, E. A., MAYNARD, A. DE L., and CORDICE J. W. V., Jr. (1953), Y. thorac. Surg., 25, 448.

PAGET, S. (r896), 'The Surgery of the Chest,' London, p. 121.

PARMLEY, L. F., MATTINGLY, T. W., and MANION, W. C. (1958), Circulation, 17, 5, 953.

REHN, L. (1897), Arch. klin. Chir., 55, 315.

SENAC, J. B. (1749), 'Traite de la structure de coeur, de son action et de ses maladies,' Paris, 2, 366

STRIEDER, J. W. (1939), f. thorac. Surg., 8, 576.

\section{HOW TO GET THERE}

An Address Book for the Medical profession, showing how to reach the various Colleges, Societies, Institutes and Hospitals in or near London

New (Fourth) Edition: 1954

Price 2s. 6d. (3s. Od., post free)

Published by the

\section{FELLOWSHIP OF POSTGRADUATE MEDICINE}

60 Portland Place, London, W.I

Bibliography continued from page 545-F. G. Smiddy, F.R.C.S.

\section{BIBLIOGRAPHY}

CHAMBERS, R., and ZWEIFACH, B. W. (1947), Amer. F. Physiol. I50, 239.

COOPER, Sir A. (1838), 'A Dictionary or Surgery,' 7th edition, London, Longman.

FARR, R. S., CLARK, S. L., and PROFFITT, J. E., Research Report, Naval Res. Inst., U.S.A., Project N.M. 00708 I, $12,02$.

FINE, J., FRANK, H. A., SCHWEINBURG, F. B., JACOB, S. W., and GORDON, T. (1952), Ann. N.Y. Acad. Sci., 55,429 .

FINE, J. (1958), Brit. F. Anaesth., 30, 455

FRANK, H. A., SELIGMAN, A. M., and FINE, J. (1946), f. clin. Invest., 25, 22.

FRANK, E., FINE, J., and PILLEMER, L. (1955), Proc. Soc. exp. Biol. (N.Y.), 89, 223.

FRANK, N. A., JACOB, S. W., FREIDMAN, E. E., RUTENBURG, S. H., and FINE, J. (1952), Amer. F. Physiol., 168, 150.

GREEN, S., MAZUR, A., and SHORR, E. (1956), f. biol. Chem., 220, 237.

JACOB, S. W., WEIZEL, H., GORDON, E., KORMAN, H., SCHWEINBURG, F. B., FRANK, H., and FINE, J. (I954), Amer. F. Physiol., 179, 523.

LANDY, M. J., and SHEAR, M. J. (1957), f. exp. Med., 106, 77. LeDRAN, H. F. (1943), A treatise, or 'Reflections Drawn from Practice on Gunshot Wounds '(translated), London, Clarke.
RAVIN, H. A., RUTENBURG, S. H., and FINE, J. (1958), Proc. Soc. exp. Biol. (N.Y.), 97, 436 .

RUTENBURG, S. H., and FINE, J. (1956), Ibid., 93, 484.

SCHWEINBURG, F. B., FRANK, H. A., and FINE, J. (1954), Amer. F. Physiol., 179, 532.

SCHWEINBURG, F. B., and FINE, J. (1955) Proc. Soc. exp. Biol. (N.Y.), 88, 589 .

SCHWEINBURG, F. B., SHAPIRO, P. B., FRANK, E. D., and FINE, J. (1958), Ibid., 95, 646 .

SHORR, E., ZWEIFACH, B. W., and FURCHGOTT, R. F. (1948), Ann. N.Y. Acad. Sci., 49, 571.

SHORR. E., ZWEIFACH, B. W., FURCHGOTT, R. F., and BAEZ, S. (195I), Circulation, 3, 42.

SMIDDY, F. G., and FINE, J. (1957), Proc. Soc. exp. Biol. (N.Y.), 96, 558 .

WEIL, M. H., MCCLEAN, L. D., VISCHER, M. B., and SPINK, W. W. (I956), Ұ. clin. Invest., 35, I 191 .

ZWEIFACH, B. W., LEE, R. E., HYMAN, C., and CHAMBERS, R. (1944), Ann. Surg., 120, 232.

ZWEIFACH, B. W., and THOMAS, L. (1957), f. exp. Med. 106, 385 .

ZWEIFACH, B. W., GORDON, H. A., WAGNER, M., and REYNIERS, J. A. (1958), Ibid., 107, 437.

ZWEIFACH, B. W., BENACERRAF B., and THOMAS, L. (1958), Ibid., ro6, 403 . 